Sciendo

\title{
Hobartian Voluntarism and Epistemic Deontologism
}

\author{
Andrei Buckareff \\ Franklin and Marshall College
}

Disputatio Vol. 2, No. 21

November 2006

DOI: $10.2478 /$ disp-2006-0011

ISSN: 0873-626X 


\title{
Hobartian voluntarism and epistemic deontologism
}

\author{
Andrei A. Buckareff \\ Franklin and Marshall College
}

\begin{abstract}
Mark Heller has recently offered a proposal in defense of a fairly strong version of doxastic voluntarism. Heller looks to the compatibilist theory of free will proposed by R.E. Hobart in the first half of the twentieth century for an account of doxastic control. Heller's defense of Hobartian Voluntarism is motivated by an appeal to epistemic deontologism. In this paper I argue that Heller's defense of a version of strong or direct doxastic voluntarism ultimately fails. I finally argue that the failure of his theory of epistemic agency does not imply the untenability of epistemic deontologism.
\end{abstract}

\section{Introduction}

Mark Heller (2000) has recently attempted to defend a strong version of doxastic voluntarism. Heller looks to the compatibilist theory of free will proposed by R.E. Hobart (1966) in the first half of the twentieth century for an account of doxastic-control. Heller's Hobartian Voluntarism is one version of a growing number of defenses of direct doxastic voluntarism — the thesis that agents can exercise direct voluntary control over their doxastic attitudes (such as belief, disbelief, and suspension of belief). Defenders of such views argue for similarities between coming to believe and the etiology of free action on compatibilist theories of free agency. ${ }^{1}$ Such 'doxastic compatibilist' theories of epistemic agency are typically motivated by an appeal to epistemic deontologism - the thesis that for any epistemic agent $S$ and proposition $p, S$ has an obligation with respect to what sort of doxastic attitude to take towards $p$. Epistemic deontologists understand epistemic justification in deontological terms, a belief that

\footnotetext{
${ }^{1}$ For other recent defenses of doxastic compatibilism, see Ryan 2003 and Steup 2000. I reply to Ryan in Buckareff Forthcoming and Steup in Buckareff 2006.

Disputatio, Vol. II, No. 21, November 2006
} 
$p$ being justified only if one has not violated any of one's epistemic obligations in believing that $p$. Heller adds the following to the core of epistemic deontologism. Violating our epistemic obligations makes us blameworthy and we are praiseworthy if we do not violate any epistemic obligations. Finally, 'justified' and 'unjustified' are understood as terms of praise and blame (Heller 2000: 130). So for Heller justification requires that agents are responsible for what they believe, which requires that agents have a strong variety of control over coming to believe.

Heller's defense of Hobartian Voluntarism is offered to make room for agents to be responsible for what they believe. If successful, he will refute premise (2) of the following type of argument against epistemic deontologism.

(1) If we have epistemic obligations, then doxastic attitudes are sometimes under our direct voluntary control.

(2) Doxastic attitudes are never under our direct voluntary control.

(3) Therefore, we do not have any epistemic obligations.

In this paper I will argue that insofar as Heller attempts to defend a strong version of doxastic voluntarism, he ultimately fails. Specifically, he fails to present a model of doxastic control that is sufficiently robust to provide agents with direct voluntary control over their doxastic attitudes and, hence, is not sufficient to falsify premise (2) in the foregoing argument. We may get some control over our beliefs if Heller is right, but it is not the direct voluntary control we must have over coming to believe if direct doxastic voluntarism is true. It will become apparent that Heller's account of doxastic control is really quite modest at best.

\section{Heller's Hobartian Voluntarism}

Unlike some others who have recently attempted to defend strong versions of doxastic voluntarism, Heller avoids trying to make sense of how an agent can be said to have the ability to do otherwise with respect to her beliefs. ${ }^{2}$ Instead, he proposes an actual sequence view

\footnotetext{
${ }^{2}$ For an example of a defense of a version of doxastic voluntarism that involves an attempt at making sense out of how an agent could have believed otherwise, see Barnes 2002.
} 
of epistemic agency to ground a deontological conception of epistemic justification. Roughly, for Heller this means that an agent exercises agency and is autonomous with respect to coming to believe only if coming to believe reflects the agent's character and is properly governed by the agent.

Heller denies the psychological possibility of believing at will. His goal is to 'see how much of the voluntaristic picture of belief can be preserved in spite of the fact that we cannot believe at will' (Heller 2000: 131). Heller does not say what he means by 'doxastic voluntarism'. But his comments and the theory of epistemic agency he provides suggest that he is attempting to defend a version of direct doxastic voluntarism (the thesis that coming to be believe can be under the direct voluntary control of an agent). So what he aims at defending is still a fairly strong species of doxastic voluntarism; although, as noted, the product he actually offers is really quite weak.

Heller claims we have what he calls 'reflective will' with respect to our beliefs. In the case of free actions this means the following. 'S has reflective will with respect to just those acts which reflect S's character or nature. The intuition is that free acts are a manifestation of who the agent is' (Heller 2000: 133). This echoes Hobart's claim that a person's character is 'the sum of a man's tendencies to action, considered in their relative strength' (1966: 66). In judging one's own actions, Hobart emphasizes that 'the act proceeded from me, the distinctive me, from the manner of man I am or was' (1966: 68). The judgment of an action is a judgment of the character of the agent. We judge the actual sequence of events that issued from an agent in making assessments of responsibility. ${ }^{3}$ So it is in this sense that an agent has reflective will with respect to actions. For Heller, things are similar with respect to beliefs and our role as epistemic agents.

In developing a theory of epistemic agency, Heller borrows from Harry Frankfurt. He suggests that 'we might take Frankfurt's hierarchical theory to be a version of the reflective will account of freedom

${ }^{3}$ This does not mean that Hobart did not provide an account of how an agent can be understood to have the ability to have acted otherwise. He provides a roughly Humean account of alternate possibilities that takes an agent's ability to do otherwise to be a hypothetical ability. He writes of free agents that after acting, they can truthfully utter, 'I could have willed whichever way I pleased. I had the power to will otherwise, there was nothing to prevent my doing so, and I should have done so if I had wanted' (Hobart 1966, 73). 
if we identify the agent, or the agent's character or nature, with her highest order desires' (Heller 2000: 134). ${ }^{4} \mathrm{He}$ then gives the following account of epistemic nature:

S's epistemic nature is her desires to form beliefs in accordance with certain dispositions rather than others. (Heller 2000: 135)

The relevant dispositions are belief-forming dispositions. Heller replaces willing actions with believing propositions. So while an agent's nature is to be understood in terms of her higher-order desires, 'the relevant higher order desires are those that are directed at belief-formation dispositions', not her first-order desires (Heller 2000: 135).

According to Heller, two types of dispositions may be endorsed by one's epistemic nature. The first are an agent's dispositions to 'endorse certain reasoning patterns, her dispositions to accept the results of those patterns when she recognizes the patterns' (Heller 2000: 136). The second are an agent's dispositions to 'recognize reasoning patterns for what they are' (Heller 2000: 136). Heller adds: 'If S forms a belief because her nature endorses either dispositions to use defective reasoning patterns or dispositions to misrecognize which pattern is being used, then that belief is a manifestation of her defective epistemic nature, and her belief is unjustified' (Heller 2000: 136).

Heller's theory of epistemic agency and the type of doxastic control that makes it possible is summarized as follows.

An event e is within S's voluntary control (and therefore she is responsible for e, providing she satisfies all of the other conditions for responsibility) just in case e follows from S's nature. . . . When the event is a belief, the bit of her nature that is relevant is her epistemic nature - those beliefforming dispositions with which she identifies. On this account of voluntary belief, it is easy to be responsible for our beliefs. Almost all of our beliefs are either justified or unjustified. (Heller 2000: 137)

Since beliefs are mental states and not events, I will take it that the acquisition of a belief is the relevant event that an agent can be responsible for.

\footnotetext{
${ }^{4}$ See Frankfurt 1988.
} 


\section{Problems with Hobartian Voluntarism}

Heller has not provided an account of how direct voluntary control can be exercised over coming to believe. The control is indirect, at best. This should seem obvious from Heller's account of an agent's epistemic nature. An agent's epistemic nature amounts to her higher-order proattitudes toward first-order belief-forming dispositions. Hobart has no such element in his theory of free action. For Hobart, what issues from your character is what determines your action and because it issues from your self, it is free. It is free if you are not coerced, and if your character had been different, including your relevant motivational states at the time of action, then you would have done otherwise. ${ }^{5}$ So you could have done otherwise if your first-order states were different. But what is most important is that the action issued from your character. Again, the emphasis is on the actual sequence, not so much on what kind of ability to do otherwise you had. There is no mention of higher-order attitudes that take first-order states as their intentional objects. If Heller followed Hobart, then the formation of a belief being caused by an agent's relevant epistemic reasons would suffice for the belief to be formed freely and therefore be under an agent's direct voluntary control. ${ }^{6}$ But this cannot be sufficient for control over actions, much less the formation of beliefs.

The current orthodoxy in the philosophy of action favors versions of the causal theory of action to account for the control agents have over their behavior that is actional. On the causal theory of action, some behavior $A$ of an agent $S$ is an action if and only if there are some non-actional mental events or states that proximately cause $S$ 's $A$-ing and constitute $S$ 's reasons for $A$-ing. ${ }^{7}$ Causalists now recognize that a merely ballistic role for the mental events and states that cause and explain behavior is not sufficient for an agent to exercise the control necessary for some behavior to be actional. ${ }^{8}$ Cases of primary causal

${ }^{5}$ See Hobart 1966, 66-77.

${ }^{6}$ James Montmarquet (1986) has argued in defense of such a strict Hobart-style claim.

${ }^{7}$ This is a rough schema for the CTA offered by Jing Zhu and myself in Buckareff and Zhu 2004.

8 'Ballistic causation' should be understood as being like what obtains when a football player's foot makes contact with a ball. The causal contact of the foot with 
deviance show this. In an example by Roderick Chisholm (1966: 30), ${ }^{9}$ an agent desires to inherit a fortune. He believes if he kills his uncle he will inherit the fortune. The occurrence of forming both his belief and desire causes the murderous nephew to drive excessively fast. The result is that he runs over and kills a pedestrian who happens to be his uncle. It seems that Chisholm's murderous nephew does not perform the action of killing his uncle. But there is an event of killing in Chisholm's scenario; and bodily activity is caused by the agent's relevant psychological items. Furthermore, the mental causes reflect the character of the agent. But the presence of the psychological items in question is only necessary and not sufficient for an action to obtain.

Hobart's theory of free action falls prey to the problem of primary causal deviance. On his account, the proximal psychological causes (specifically, the present-directed intentions of agents) do not play a causally sustaining role, monitoring, and guiding behavior by being responsive to afferent feedback. ${ }^{10}$ And they are not self-referring. That is, Hobart has no requirement that some psychological item counts as a cause with respect to doing some action only if the agent performing the action can also conclude that the mental state in question will be instrumental in performing the action. ${ }^{11}$ These are just two representative proposals that defenders of causal theories of action have offered to resolve the problem of causal deviance which Hobart's own theory of free action lacks. Fortunately, the Hobartian theory of free action can be fixed by appropriating some of the resources offered by contemporary causal theories of action. But such solutions to the control problem will not help us in epistemology. Let me explain.

the ball does all of the work. Neither the agent nor some proper part of the agent causally sustains the ball along its trajectory, ensuring that it make it past the goalkeeper and into the net. All of the causal activity can be indexed to one moment of time. If you would like, ballistic causation can be thought of as synchronic causation, while diachronic causation is what obtains when causal activity sustains some process or event from its initiation through its completion.

${ }^{9}$ Cf. Donald Davidson's example of the unnerved climber in Davidson 1980, 79.

${ }^{10}$ For an example of how intentions might play a guiding and sustaining role, see Thalberg 1984, 257. For similar proposals, see Bishop 1989; Brand 1984; Buckareff and Zhu 2004; Mele 1992; Mossel 2005; and Searle 1983.

${ }^{11}$ For an example of self-referring mental states, particularly self-referring intentions in action, see Harman 1997. 
On Heller's account, when epistemic agency is exercised, epistemic reasons cause the event of coming to believe. If the causal role of one's epistemic reasons is merely ballistic, the effect, not surprisingly, is that one comes to believe. Control over the event is not vitiated by the way the event is caused. Suppose the causal role of epistemic reasons is more like the causes of action. So, for instance, the epistemic reasons play a guiding and sustaining role in the acquisition of a belief. No more control over coming to believe would be exercised as a consequence. The agent would still come to believe, and both the event of coming to believe and the end state of belief would be no more under the agent's control than if the causal relation between the epistemic reasons and coming to believe is merely ballistic. The causal role of epistemic reasons in the etiology of belief does nothing to afford us more or less control over our beliefs. Why should we expect this result?

The role of the two types of reasons, epistemic and practical, are fundamentally different with respect to their functions and how they figure in controlling our behavior. ${ }^{12}$ In the case of action, the role an agent's practical reasons play in bringing some behavior under an agent's control makes all the difference in whether or not some behavior is actional. The role of practical reasons, as reasons for action, is to bring about some end achieved by acting. They guide our intentional behavior toward the fulfillment of our practical goals. Our pro-attitudes, in particular, represent bringing about some effect in the world (where this includes the mind) - i.e., desires and intentions have a world to mind direction of fit, the function of such attitudes being to bring the world to conform to the mind of the agent. ${ }^{13}$ And when we engage in practical deliberation we aim at conforming the world to our pro-attitudes.

Epistemic reasons are quite different. Epistemic reasons are reasons for believing the truth of a proposition; they are not reasons for performing an action. They provide the source of the alethic considerations that favor taking something as true. The mind conforms to

\footnotetext{
${ }^{12}$ For more on the differences between the two types of reasons, see Audi 1993 and 2001. See also Kelly 2002, and Velleman 2000. It is worth noting that I am here using 'practical reasons' to refer to all of the causal antecedents of action which may figure in an explanation of an action. So I am including intentions as practical reasons.

${ }^{13}$ See Anscombe 1963 and Searle 1983 for more on direction of fit.
} 
the way the world is represented in consciousness (regardless of whether or not the world actually is the way it is represented in consciousness) - in particular, beliefs have a mind to world direction of fit, the function of reasons for belief being to conform the mind to the world. When a belief is formed on the basis of epistemic reasons, the acquisition of the belief is a wholly passive affair that is quite unlike an action. If epistemic reasons provided the means of controlling attitudes, then they would share the same direction of fit and function as practical reasons. We would entertain them with the goal of actively changing our minds, not with the goal of having our minds conform to the way the world is.

Of course, practical reasons can play a role in exercising manipulative control over our doxastic attitudes. ${ }^{14}$ They may do this by directing our agency aimed at bringing it about that we form some desired doxastic attitude. However, they do not provide the basis for forming the attitude. That is, while an agent may desire and intend to believe $p$ and take steps to bring it about that she believes $p$, the reasons for which the agent believes $p$ will be (putative or actual) epistemic reasons. So the actual final event of coming to believe is itself passive and occurs in response to what an agent takes to be alethic considerations. This is the case even if coming to believe and the end state of believing can accurately be described as the intentional outcome of an agent's exercise of manipulative control over her doxastic attitudes. ${ }^{15}$

Heller affords no role to practical reasons in coming to believe. If he did, then perhaps he would have an account of exercising direct voluntary control over coming to believe at the expense of having an account of responsible epistemic agency. It is worth noting that Heller's concern for having a theory of epistemic agency that does not dispense with epistemic justification as a desideratum in exercising control can be additionally motivated by a concern for broadly rational agency, not just epistemically rational agency. For instance, given an agent's desire to have an epistemically justified belief that $p$ the demands of practical rationality would seem to require that the agent forms her belief on the basis of epistemic reasons and that

\footnotetext{
${ }^{14}$ See Hieronymi 2006 for more on the varieties of doxastic control, including manipulative control.

${ }^{15}$ I discuss the role practical reasons may play in brining it about that one believe a proposition in Buckareff 2004. See also Hieronymi 2006 and Kelly 2002.
} 
practical reasons play no direct role in the etiology of the belief. Specifically, the responsible epistemic agent for Heller will want to have her beliefs formed by belief-forming dispositions that produce epistemically justified beliefs. Such an agent would be practically rational if she comes to believe on the basis of epistemic reasons, not practical reasons. If an agent wants to have epistemically justified beliefs, she ought to have her beliefs formed by the right beliefforming dispositions. So Heller cannot afford practical reasons a direct role in controlling belief given his concern for epistemic justification, and to do so would mean endorsing a strategy of belief control that would require that agents also be practically irrational, assuming they have the goal of having epistemically justified beliefs. ${ }^{16}$ Whether or not he is concerned with anything like a broad conception of rational agency, Heller wisely avoids affording practical reasons a direct role in his account of doxastic control.

Returning to doxastic control, the Frankfurtian element in Heller's theory of epistemic agency is where space is made for doxastic control by an agent. According to Heller, simply having the relevant belief-forming dispositions cause the formation of a belief is not sufficient for the belief to be free. The agent must identify with certain belief-forming dispositions. To identify with a particular disposition is to make it part of one's epistemic nature, a part of oneself. But notice that the locus of control seems to be in the mental act of identifying with one's belief-forming dispositions, not in the belief-forming dispositions themselves, or in coming to believe. Some of the belief-forming dispositions an agent identifies with operate wholly outside of her control, even if the agent identifies with them and regards them as part of herself. For instance, some belief-forming processes are not always actional and under an agent's control and some are never actional. They are automatic, involving no agency. The agency and control exercised by an agent is merely in identifying with the processes. So the locus of control for the acquisition of any beliefs as a consequence of such processes is in the agent's higherorder act of identifying with her first order belief-forming dispositions when she desires to have a certain epistemic character. What an agent is always active with respect to is what sorts of belief-forming

\footnotetext{
${ }^{16}$ Of course, some may object that I am presupposing a form of instrumentalism about practical rationality. I do not find instrumentalism objectionable. But to defend it here would go beyond the scope of this essay.
} 
dispositions she identifies with which constitute the epistemic character she forms. And on the occasions when some reasoning, or whatever mental activity that an agent identifies with is actional, it is the locus of control and responsibility. No control is exercised after the reasoning or whatever has ceased. Any responsibility for beliefs, and hence any duties, is derivative from what she exercises direct voluntary control over. She is indirectly responsible for what she believes at best. What she is directly responsible for is whether or not she identifies with the right belief-forming dispositions that come to constitute her epistemic character for the right reasons. This does not get Heller a species of direct doxastic voluntarism. It is indirect doxastic voluntarism.

On Heller's behalf, my opponent may argue as follows. 'You have admitted that an agent is responsible for identifying with belief-forming dispositions, and that her epistemic nature is constituted by those belief-forming dispositions. It seems, then, that if her beliefs reflect her epistemic nature, being caused in the appropriate way by the relevant epistemic dispositions, then the agent is responsible for her beliefs. The agent is responsible for her beliefs in the same way that an agent is responsible for her actions that reflect her character when you combine Hobart's theory of free action with Frankfurt's account of identifying with desires. Actions which reflect an agent's character are under the control of an agent. Similarly, an agent's coming to believe meets the control requirement because the belief is caused by a part of an agent and reflects her epistemic nature. This is like in Frankfurt's account of free will. Just as in Frankfurt's account, to have free will means that one has the will one wants to have (Frankfurt 1988: 20), so also coming to believe is free if one has the epistemic nature one wants and one's belief is caused by one's epistemic nature. So coming to believe is under an agent's direct voluntary control given that it issues from the epistemic nature one wants to have'.

This reply suffices to show that Heller has provided a plausible account of what is sufficient for a free epistemic nature. But if we are to exercise direct voluntary control over our beliefs, then our control over coming to believe needs to be under our control like our free actions. And the foregoing response fails to recognize the difference between how we control our epistemic natures in having a free epistemic nature versus how we directly control our actual beliefs.

I have claimed that, if we assume that identifying is a mental action over which human agents can exercise direct voluntary control, the 
consequences of our identifying with belief-forming dispositions are only under our indirect voluntary control. We exercise control via the act of identifying. But the consequences of identifying are not under our direct voluntary control. What is under our direct voluntary control is how we act. Frankfurt requires that some behavior be under an agent's control in order for it to be actional; having a free will alone is not enough for whatever flows from one's character and will to be under one's control and thus actional, much less free. In the case of overt action, Frankfurt writes that 'When we act, our movements are purposive. This is merely another way of saying that their course is guided' (1988: 73). Frankfurt is quite critical of placing all control in the causal antecedents of some behavior. In order for behavior to be actional and, therefore, under our control, it must be purposive. Frankfurt writes that:

Behavior is purposive when its course is subject to adjustments which compensate for the effects of forces which would otherwise interfere with the course of the behavior, and when the occurrence of these adjustments is not explainable by what explains the state of affairs that elicits them. The behavior is in that case under the guidance of an independent causal mechanism, whose readiness to bring about compensatory adjustments tends to ensure that the behavior is accomplished. The activity of such a mechanism is normally not, of course, guided by us. Rather it is, when we are performing our action, our guidance of our behavior. Our sense of our own agency when we act is nothing more than the way it feels to us when we are somehow in touch with the operation of mechanisms of this kind, by which our movements are guided and their course guaranteed. (Frankfurt 1988: 74-75)

I noted how causal theorists of action have modified their theories of action in response to critics such as Frankfurt. Unlike Frankfurt, causalists maintain that behavior must be guided and monitored by its psychological causes in order for it to be actional. I also noted that Heller cannot avail himself of the same strategy causalists employ in theorizing about action in providing an account of how coming to believe can be purposive and, hence, under the control of an agent. And he certainly does not help himself to anything like what Frankfurt argues is necessary for behavior to be purposive and, therefore, actional.

The foregoing suggests the following argument against Heller. If behavior is only under our control and, therefore, purposive and actional, only if it is properly guided and monitored by an agent or 
some proper part of an agent, then the causal outputs of our beliefforming dispositions which are not under our direct voluntary control are not under our control in the way that our actions are. If this is the case, then our doxastic attitudes such as belief are not under our direct voluntary control. So our beliefs are not under our direct voluntary control. And they fail to be under our direct voluntary control, even if our coming to believe reflects our epistemic natures in the sense that Heller suggests. Our activity with respect to our beliefs is importantly unlike that with respect to our actions. Epistemic agency is exercised at the level of performing actions that affect what we come to believe; but coming to believe is itself outside of our direct voluntary control, even if our epistemic natures can be free.

\section{What about epistemic deontologism?}

Recall that many who defend strong versions of doxastic voluntarism do so as part of a defense of epistemic deontologism. Specifically, they object to

(2) Doxastic attitudes are never under our direct voluntary control.

If (2) is true, then it follows, by modus tollens from

(3) If we have any epistemic obligations, then doxastic attitudes must sometimes be under our direct voluntary control.

that we do not have any epistemic obligations; and, therefore, epistemic deontologism is false. Heller has failed to show that (2) is false. At best normal human agents get indirect voluntary control over coming to believe on his theory of epistemic agency. But must epistemic deontologists defend (1), forcing them to attempt to argue that (2) is false? It seems they do not have to accept (1). So the better strategy is to argue that the consequent of the conditional expressed by premise (1) is false, while arguing that epistemic agents have epistemic obligations although they cannot exercise any direct voluntary control over their doxastic attitudes. Such a strategy has been adopted by others, most notably Richard Feldman (2001 and 2004). ${ }^{17}$

\footnotetext{
${ }^{17}$ Jonathan Adler also defends the claim that agents can have epistemic obligations if they do not have direct voluntary control over their beliefs. But, unlike
} 
The approach favored by Feldman is to regard the 'oughts' implied by deontic epistemic norms to be what he calls 'role oughts' (2004: 175; 2001: 87-89). Epistemic oughts, according to Feldman, 'describe the right way to play a certain role' (Feldman 2001: 88). It is constitutive of being a normal adult human being that one comes to have doxastic attitudes and at any time simultaneously has a wide range of dispositional and occurrent doxastic attitudes. So a role every normal adult human occupies is that of being a believer. Regarding this role, Feldman writes that:

the right way to carry out one's role as a believer is to form beliefs that are supported by one's current evidence. That is, if one is considering a proposition, then one ought to believe it if one's evidence supports it, ought to disbelieve it if one's evidence goes against it, and ought to suspend judgment if one's evidence is neutral. (Feldman 2001: 88)

According to Feldman, the application of epistemic oughts does not imply that agents have direct voluntary control over their beliefs. Even if believing is unavoidable, an agent has an obligation to believe that $p$ if her evidence overwhelmingly supports the truth of $p$ and is epistemically prohibited from adopting a contrary doxastic attitude towards $p$. Epistemic norms, including the proper application of epistemic oughts, are based on what constitutes good performance in this case, as a believer. What occurs may be wholly outside of a believer's control. But there is a doxastic attitude she ought to take or is permitted to take towards a proposition when presented with the evidence for the truth of the proposition. Justification is wholly a function of the evidence an agent has for the truth of a proposition on which her belief is based, or would be based were she to form a belief. ${ }^{18}$ So what one ought to believe is what one is justified in believing. And being a believer is what subjects one to epistemic oughts, not the ability to exercise direct voluntary control over one's beliefs.

Assuming the foregoing is right, what value is there in having the sort of control we get with Heller's Hobartian Voluntarism? While I believe Feldman makes a convincing case for taking deontic epistemic

Feldman, Adler argues that agents can still be responsible for their beliefs even if they lack control over their beliefs. See Adler 2002, especially chapter 2.

${ }^{18}$ For defenses of this claim, see Conee and Feldman 2004 and Feldman and Conee 2004. 
norms and the oughts we associate with them to be role norms and oughts, there is still some value in having indirect voluntary control over our beliefs. Feldman admits that construing epistemic oughts as role oughts may not suffice for ascribing praise and blame to epistemic agents $(2001: 89 ; 2004: 175)$. If this is so, then the locus of praise and blame should be in the activity that is under an agent's direct voluntary control — e.g., in endorsing or identifying with certain belief-forming dispositions over others. So room for epistemic praise and blame is made on a theory of epistemic agency such as Heller's. But the locus of responsibility is in the agency exercised by an agent, not in coming to believe.

While Heller clears space for epistemic responsibility, being epistemically responsible is not the same thing as having an epistemically justified belief. Most people never consciously identify with beliefforming dispositions. I suspect that very few people have an idea of what kind of person they want to be epistemically. If they do, I would be surprised if agents consciously identify with very many specific belief-forming dispositions. I know that I do not. If you ask them why they believe that $p$, or ask why one ought to believe that $p$, they will enumerate reasons they have for believing that $p$. The situation is different in the case of practical responsibility and autonomous action. When it comes to the motivational antecedents of intentional behavior, agents will often express personal policies which reflect higher-order preferences they have which motivate them to identify with certain desires they have over others. For instance, I may want to lose weight and develop a policy that I will avoid fatty food. When presented with an opportunity to eat a salad or French fries, I identify with my desire to eat a salad over my desire to eat French fries because to eat the French fries would not be consistent with my higher-order policy to avoid fatty foods which expresses my intrinsic desire to lose weight.

I admit that we occasionally identify with belief-forming dispositions; but we seem to consciously do this far less often than we form higher-order policies and identify with motivational states that affect how we act. But while the sort of personal autonomy with respect to our actions that we get by identifying with certain desires over others may be necessary for us to be practically responsible, and something similar is required for epistemic responsibility, no such autonomy is required for epistemic justification. Consider two agents. One identifies with a particular belief-forming disposition. The other does not identify with any particular belief-forming dispositions and has no 
antecedent desire to believe in accordance with some dispositions over others. Both of them base their belief that $p$ on the same evidence. It seems odd to suggest that the epistemic responsibility of the first agent puts her in a better position with respect to the justification of her belief than the other agent. They will both offer the same reasons for believing that $p$ when asked why they believe that $p$. But now suppose they are both epistemically responsible. One has more evidence for $p$ than the other. It seems the stronger epistemic justification of the belief of the agent with more evidence is solely a function of his evidence and has nothing to do with his being epistemically responsible. Granted, being epistemically responsible in Heller's sense will make it more likely that an agent's belief that $p$ is justified. After all, one will probably be more conscientious if one is epistemically responsible. But despite the great value of being epistemically responsible, it certainly is not a necessary condition for epistemic justification.

\section{Conclusion}

I have shown that Heller's Hobartian Voluntarism is best taken to be an indirect or weak doxastic voluntarism, hardly sufficient to falsify (2) in the argument against epistemic deontologism. But, using the work of Richard Feldman, I have suggested that even if we cannot have direct voluntary control over any of our beliefs, it seems that some species of epistemic deontologism is viable. Moreover, there is still some value in defenses of versions of doxastic voluntarism such as Heller's. For if Heller's theory is recast as a version of indirect or weak doxastic voluntarism, then perhaps we can make sense of the propriety of ascribing praise or blame to agents for the formation of their beliefs. But we may still have epistemic duties and, hence, it is proper to use epistemic ought-statements in our epistemological discourse whether or not we can exercise any meaningful control over our beliefs - however indirect and weak such control may be. ${ }^{19}$

Andrei A. Buckareff Dept. of Philosophy, Franklin and Marshall College P.O. Box 3003, Lancaster, Pennsylvania 17604-3003, U.S.A. andrei.buckareff@fandm.edu

\footnotetext{
${ }^{19}$ Thanks to Earl Conee, Richard Feldman, and a referee for this journal for helpful comments on earlier drafts of this paper.
} 


\section{References}

Adler, Jonathan. 2002. Belief's Own Ethics. Cambridge, MA: MIT Press.

Anscombe, G.E.M. 1963. Intention. Oxford: Blackwell.

Audi, Robert. 1993. The Architecture of Reason. In The Structure of Justification Cambridge: Cambridge University Press, 1993.

Audi, Robert. 2001. The Architecture of Reason: The Substance and Structure of Rationality. Oxford: Oxford University Press.

Barnes, Gordon. 2002. Belief, Control, and Conclusive Reasons. The Southern Journal of Philosophy 40: 315-325.

Bishop, John. 1989. Natural Agency: An Essay on the Causal Theory of Action. Cambridge: Cambridge University Press.

Brand, Myles. 1984. Intending and Acting: Toward a Naturalized Action Theory. Cambridge, MA: MIT Press.

Buckareff, Andrei A. 2004. Acceptance and Deciding to Believe. Journal of Philosophical Research 29: 173-191

Buckareff, Andrei A. 2006. Doxastic Decisions and Controlling Belief. Acta Analytica 21: 102-114.

Buckareff, Andrei A. Forthcoming. Compatibilism and Doxastic Control. Philosophia.

Buckareff, Andrei A., and Zhu, Jing. 2004. Causalisms Reconsidered. Dialogue 43: 147-155.

Chisholm, Roderick. 1966. Freedom and Action. In Freedom and Determinism, ed. by Keith Lehrer. New York: Random House.

Conee, Earl, and Feldman, Richard. 2004. Internalism Defended. In Evidentialism: Essays in Epistemology, by Earl Conee and Richard Feldman. Oxford: Oxford University Press.

Davidson, Donald. 1980. Freedom to Act. In Essays on Actions and Events. Oxford: Oxford University Press.

Feldman, Richard. 2001. Voluntary Belief and Epistemic Evaluation. In Knowledge, Truth, and Duty: Essays on Epistemic Justification, Responsibility and Virtue, ed. by Matthias Steup. Oxford: Oxford University Press.

Feldman, Richard. 2004. The Ethics of Belief. In Evidentialism: Essays in Epistemology, by Earl Conee and Richard Feldman. Oxford: Oxford University Press.

Feldman, Richard, and Conee, Earl. 2004. Evidentialism. In Evidentialism: Essays in Epistemology, by Earl Conee and Richard Feldman. Oxford: Oxford University Press.

Frankfurt, Harry. 1988. The Importance of What We Care About. Cambridge: Cambridge University Press.

Harman, Gilbert. 1997. Practical Reasoning. In The Philosophy of Action, ed. by Alfred R. Mele. Oxford: Oxford University Press. 
Heller, Mark. 2000. Hobartian Voluntarism: Grounding a Deontological Conception of Epistemological Justification. Pacific Philosophical Quarterly 81: 130-141

Hieronymi, Pamela. 2006. Controlling Attitudes. Pacific Philosophical Quarterly 87: 45-74.

Hobart, R.E. 1966. Free Will as Involving Determination and Inconceivable Without It. In Free Will and Determinism, ed. by Bernard Berofsky. New York: Harper and Row.

Kelly, Thomas. 2002. The Rationality of Belief and Some Other Propositional Attitudes. Philosophical Studies 110: 163-196;

Mele, Alfred R. 1992. Springs of Action: Understanding Intentional Behavior. Oxford: Oxford University Press.

Montmarquet, James. 1986. The Voluntariness of Belief. Analysis 46: 4953.

Mossel, Benjamin. 2005. Action, Control, and Sensations of Acting. Philosophical Studies 124: 129-180.

Ryan, Sharon. 2003. Doxastic Compatibilism and the Ethics of Belief. Philosophical Studies 114: 47-79.

Searle, John. 1983. Intentionality: An Essay in the Philosophy of Mind. Cambridge: Cambridge University Press.

Steup, Matthias. 2000. Doxastic Voluntarism and Epistemic Deontology. Acta Analytica 15: 25-56.

Thalberg, Irving. 1984. Do Our Intentions Cause our Intentional Actions? American Philosophical Quarterly 21: 249-260.

Velleman, J. David. 2000. The Possibility of Practical Reason. In The Possibility of Practical Reason. Oxford: Oxford University Press. 